\title{
PENGARUH PENAMBAHAN TEPUNG AMPAS TAHU TERHADAP KADAR SERAT PANGAN DAN KARAKTERISTIK ORGANOLEPTIK OTAK-OTAK IKAN PATIN
}

\author{
Ahmad Alim Junnatul Haq*, Titik Dwi Sulistiyati \\ Teknologi Hasil Perikanan, Fakultas Perikanan dan Ilmu Kelautan, \\ Universitas Brawijaya, Malang, \\ *Koresponden penulis : junnatul@gmail.com
}

\begin{abstract}
Abstrak
Saat ini pemanfaatan ampas tahu kurang maksimal, padahal ampas tahu memiliki banyak kelebihan seperti mengandung protein, mengandung serat, murah dan mudah didapat. Berdasarkan permasalahan tersebut maka penelitian ini melakukan penambahan tepung ampas tahu pada produk otak-otak ikan. Konsentrasi penambahan tepung ampas tahu yang diberikan yaitu 0\%, 5\%, 10\%, dan 15\% dari berat daging ikan. Metode yang digunakan dalam penelitian ini yaitu eksperimen. Data yang diperoleh dianalisis menggunakan ANOVA (Analysis of Variance) untuk mengetahui pengaruh perlakuan terhadap kadar serat pangan dan karakteristik Organoleptik otak-otak ikan. Analisa parameter organoleptik menggunakan Kruskal-Wallis. Penentuan perlakuan terbaik menggunakan metode de Garmo. Hasil penelitian menunjukkan hasil terbaik pada perlakuan 5\% penambahan tepung ampas tahu dengan kadar serat pangan sebesar $6,65 \%$, serat pangan larut 2,69\%, serat pangan tidak larut sebesar 3,96\%, protein sebesar 9,41\%, kadar air sebesar 51,33\%, lemak 1,09\%, abu 1,97\%, karbohidrat sebesar 36,20\%, hedonik kenampakan sebesar 3,52, hedonik aroma sebesar 3,34, hedonik rasa sebesar 3,54, hedonik tekstur sebesar 3,52 dan kekenyalan sebesar 9,32.
\end{abstract}

Kata kunci : Otak-otak ikan, tepung ampas tahu, eksperimen, perlakuan

\begin{abstract}
Currently the use of tofu dregs is not optimal, even though it has many advantages such as containing protein, containing fiber, cheap and easy to obtain. This research was carried out by adding tofu dregs flour to fish brains products. The concentration of adding tofu dregs flour given was $0 \%, 5 \%, 10 \%$, and $15 \%$ by weight of fish meat. The method used in this research was experiment. The data obtained were analyzed using ANOVA (Analysis of Variance) to determine the effect of treatment on levels of dietary fiber and organoleptic characteristics of fish brains. Organoleptic parameter was analyzed using Kruskal-Wallis. Determination of the best treatment was applied the de Garmo method. The results showed the best results in the treatment of $5 \%$ addition of tofu dregs flour with food fiber content of $6.65 \%$, soluble food fiber $2.69 \%$, insoluble food fiber of $3.96 \%$, protein of $9.41 \%$, high levels of water was $51.33 \%$, fat was $1.09 \%$, ash was $1.97 \%$, carbohydrate was $36.20 \%$, appearance hedonic was 3.52 , aroma hedonic was 3.34 , taste hedonic was 3.54 , texture hedonic was 3.52 and the elasticity was 9.32 .
\end{abstract}

Keywords : Fish product, tofu dregs flour, experiment, treatment

\section{PENDAHULUAN}

Otak-otak ikan merupakan produk diversifikasi hasil perikanan yang dibuat dari lumatan daging ikan. Bahan baku utama otakotak ikan adalah daging ikan segar, namun dalam proses pembuatannya ditambahkan berbagai bahan lain agar daging ikan tersebut bisa menjadi otak-otak. Di Indonesia otak- otak ikan sudah banyak tersebar di berbagai daerah. Selain mudah didapatkan, otak-otak ikan memiliki rasa yang enak dan harga yang cukup murah sehingga otak-otak ikan disukai oleh masyarakat Indonesia. Berdasarkan penelitian [1] kadar serat pada otak-otak sebesar 1,35\%. [2] Menurut hasil survei nasional tahun 2001, rata-rata penduduk Indonesia mengonsumsi serat $10,5 \mathrm{~g} / \mathrm{hari}$ 
dimana anjuran konsumsi serat rata-rata adalah $30 \mathrm{~g} /$ hari.

Pada penelitian ini dilakukan penambahan tepung ampas tahu pada produk otak-otak ikan yang dimaksudkan untuk menambah kandungan serat pangan dimana produk otak-otak standar yang ada saat ini terbuat dari bahan yang simple hanya terdiri dari daging ikan, tepung sagu, telur dan bumbu. Sehingga adanya penambahan ini diharapkan dapat menambah kandungan serat pangan dari produk otak-otak ikan.

Tepung ampas tahu adalah ampas tahu yang telah dikeringkan, sedangkan ampas tahu adalah limbah dari pengolahan tahu. Dalam $100 \mathrm{~g}$ tepung ampas tahu menurut [3] mengandung air $5,74 \%$, protein $10,80 \%$, abu $9,02 \%$, lemak $14,49 \%$, serat pangan total $47,72 \%$, serat pangan tidak larut $38,26 \%$, dan serat pangan larut $9,46 \%$. Kandungan gizi ampas tahu yang tinggi dimungkinkan untuk diolah kembali menjadi berbagai macam produk.

\section{METODE}

Metode yang digunakan pada penelitian ini adalah metode eksperimen dengan 4 perlakuan. Variabel bebas dalam penelitian ini adalah perbedaan konsentrasi tepung ampas tahu dalam pembuatan otak-otak ikan dan Variabel terikat pada penelitian ini yaitu karakteristik fisika (tekstur), kimia (protein, air, lemak, abu, dan serat pangan) dan organoleptik (penampakan, aroma, rasa dan tekstur) otak-otak ikan.

Data hasil uji fisik dianalisis dengan ANOVA (Analysis of Variance) dan jika didapatkan hasil berbeda nyata maka dilakukan uji lanjut Tukey, sedangkan pada uji organoleptik dianalisa dengan uji KruskalWallis dengan menggunakan software SPSS versi 25. Penentuan terbaik menggunakan metode De Garmo.

\section{HASIL DAN PEMBAHASAN}

\section{Karakteristik organoleptik otak-otak ikan penambahan tepung ampas tahu}

Karakteristik organoleptik otak-otak ikan meliputi, hedonik kenampakan, hedonik aroma, hedonik rasa dan hedonik tekstur.

\section{Hedonik Kenampakan}

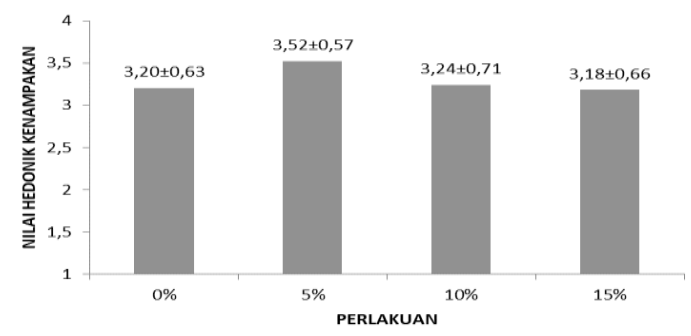

Gambar 1. Grafik hedonik kenampakan otak-otak ikan penambahan tepung ampas tahu

Nilai penampakan dengan rata-rata tertinggi terdapat pada perlakuan 5\% penambahan tepung ampas tahu yaitu sebesar $(3,52 \pm 0,57)$ sedangkan rata-rata terendah terdapat pada perlakuan $15 \%$ penambahan tepung ampas tahu yaitu sebesar $(3,18 \pm 0,66)$. Hal ini dikarenakan ukuran partikel tepung ampas tahu yang lebih besar dari tepung sagu sehingga semakin bayak penambahan tepung ampas tahu dapat menimbulkan warna yang kurang seragam. Sesuai pendapat [4], bahwa tepung ampas tahu yang diolah menghasilkan warna kekuningan cerah, dan mempunyai tekstur kurang halus

\section{Hedonik Aroma}

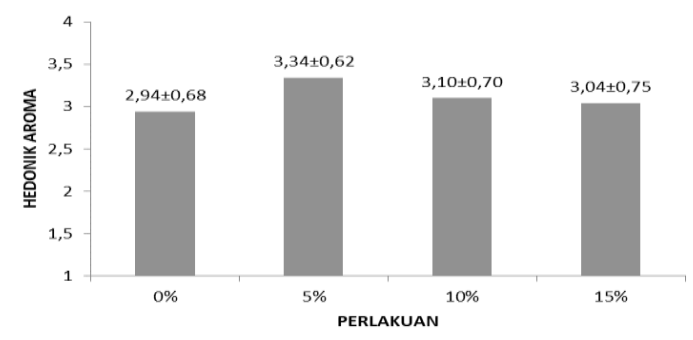

Gambar 2. Grafik hedonik aroma otak-otak ikan penambahan tepung ampas tahu

Nilai aroma rata-rata tertinggi terdapat pada perlakuan $5 \%$ penambahan tepung ampas tahu yaitu sebesar $(3,34 \pm 0,62)$ sedangkan rata-rata terendah terdapat pada perlakuan $0 \%$ penambahan tepung ampas tahu yaitu sebesar $(2,94 \pm 0,68)$. Hal ini karena penambahan tepung ampas tahu dapat menyamarkan aroma amis dari ikan patin. Menurut [5], Pada pembuatan sosis menggunakan $100 \%$ daging ikan lele dumbo, dihasilkan produk sosis yang memiliki aroma 
anyir khas ikan, sehingga kurang menarik konsumen.

\section{Hedonik Rasa}

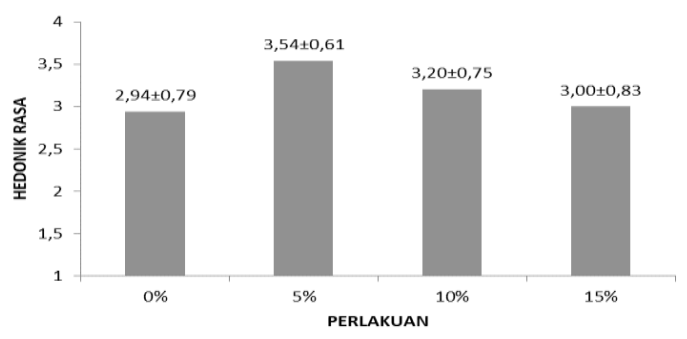

Gambar 3. Grafik hedonik rasa otak-otak ikan penambahan tepung ampas tahu

Nilai rasa rata-rata tertinggi terdapat pada perlakuan 5\% penambahan tepung ampas tahu yaitu sebesar $(3,54 \pm 0,61)$ sedangkan rata-rata terendah terdapat pada perlakuan $0 \%$ penambahan tepung ampas tahu yaitu sebesar $(2,94 \pm 0,79)$. Hal ini dikarenakan panelis menyukai rasa gurih yang ditimbulkan oleh asam glutamat dari daging ikan dan tepung ampas tahu. Sesuai pendapat [6], bahwa dari segi rasa menunjukkan bahwa penambahan tepung ampas tahu pada produk dapat menambah citra rasa semakin tinggi. Namun penambahan tepung ampas tahu yang terlalu banyak juga kurang disukai panelis karena tepung ampas tahu yang semakin kuat terasa. Hal ini sesuai dengan pendapat [7], bahwa semakin banyak substitusi tepung ampas tahu maka rasa yang dihasilkan semakin terasa ampas tahu.

\section{Hedonik Tekstur}

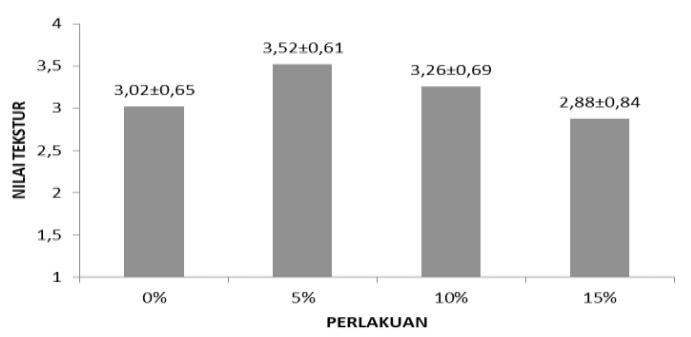

Gambar 4. Grafik hedonik tekstur otak-otak ikan penambahan tepung ampas tahu

Nilai tekstur rata-rata tertinggi terdapat pada perlakuan $5 \%$ penambahan tepung ampas tahu yaitu sebesar $(3,52 \pm 0,61)$ sedangkan rata-rata terendah terdapat pada perlakuan $15 \%$ penambahan tepung ampas tahu yaitu sebesar $(2,88 \pm 0,84)$. Hal ini dikarenakan semakin tinggi penambahan tepung ampas tahu, tekstur otak-otak ikan semakin kurang kenyal. Tepung ampas tahu kurang mengandung amilopektin sehingga tidak memiliki kemampuan membentuk gel. Sesuai pendapat [8] tepung ampas tahu mempunyai sifat tidak mampu membentuk gel sehingga kurang dapat mengikat air dan bahan bahan lain.

\section{Karakteristik Fisika}

Karakteristik fisika otak-otak ikan meliputi kekenyalan

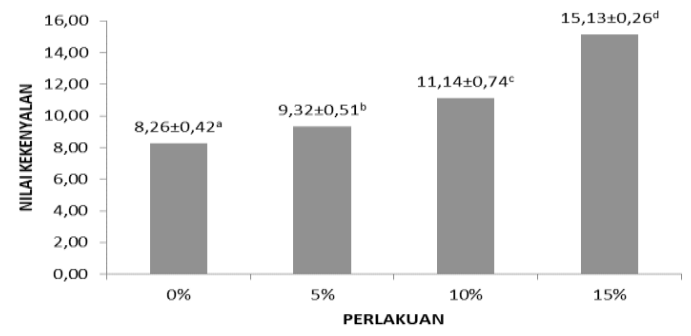

Gambar 5. Grafik kekenyalan otak-otak ikan penambahan tepung ampas tahu

Berdasarkan Gambar 5 didapatkan nilai kekenyalan otak-otak ikan patin dengan penambahan tepung ampas tahu berkisar antara 8,26-15,13. Berdasarkan hasil uji Kruskal-Wallis dapat dianalisis bahwa perlakuan penambahan tepung ampas tahu berpengaruh nyata $(\mathrm{p}<0,05)$ terhadap kekenyalan otak-otak ikan patin.

\section{Kadar serat pangan}

Kadar serat pangan otak-otak ikan meliputi, serat pangan total, serat pangan larut, dan serat pangan tidak larut

\section{Serat Pangan Total}

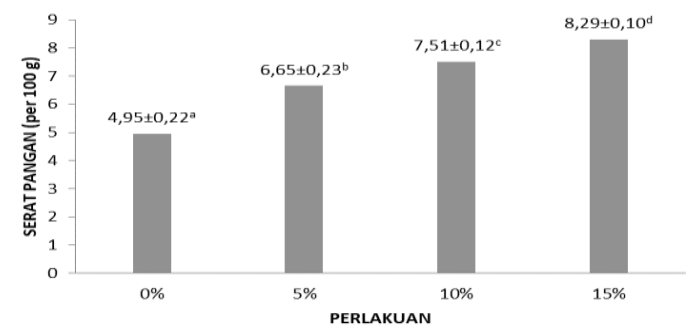

Gambar 6. Grafik serat pangan total otak-otak ikan penambahan tepung ampas tahu 
Berdasarkan Gambar 6 didapatkan nilai serat pangan total otak-otak ikan patin penambahan tepung ampas tahu berkisar antara 4,95-8,29. Berdasarkan hasil analisa bahwa perlakuan penambahan tepung ampas tahu berpengaruh nyata $(p<0,05)$ terhadap serat pangan total otak-otak ikan patin

\section{Serat Pangan Larut}

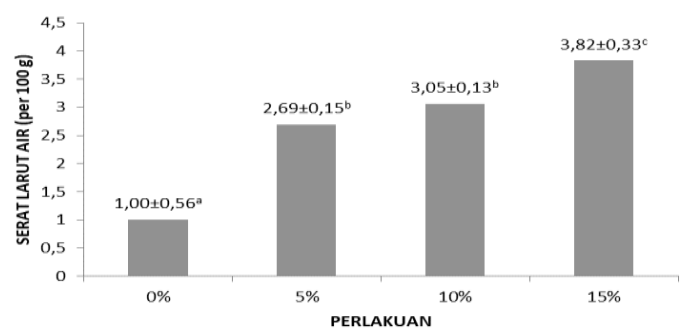

Gambar 7. Grafik serat pangan larut otak-otak ikan penambahan tepung ampas tahu

Berdasarkan Gambar 7 didapatkan nilai serat pangan larut otak-otak penambahan tepung ampas tahu berkisar antara 1,00-3,82. Berdasarkan hasil analisa bahwa perlakuan penambahan tepung ampas tahu berpengaruh nyata $(\mathrm{p}<0,05)$ terhadap serat pangan larut otak-otak ikan patin

\section{Serat Pangan Tak Larut}

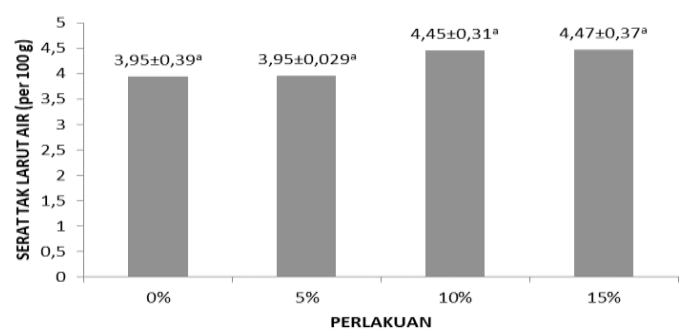

Gambar 8. Grafik serat pangan tak larut otak-otak ikan penambahan tepung ampas tahu

Berdasarkan Gambar 8 didapatkan nilai serat pangan tidak larut otak-otaak ikan patin penambahan tepung ampas tahu berkisar antara 3,95-4,47. Berdasarkan hasil ANOVA dapat dianalisis bahwa perlakuan penambahan tepung ampas tahu berpengaruh nyata $(\mathrm{p}<0,05)$ terhadap serat pangan tidak larut otak-otak ikan patin.

\section{Penentuan perlakuan terbaik}

Penentuan perlakuan terbaik yang didapatkan menggunakan metode De Garmo adalah perlakuan konsentrasi penambahan tepung ampas tahu sebanyak 5\%. Adapun karakteristik otak-otak ikan dengan penambahan tepung ampas tahu terbaik pada Tabel 1.

Tabel 1. Otak-Otak Ikan Dengan Penambahan Tepung Ampas Tahu Terbaik

\begin{tabular}{lcc}
\hline \multicolumn{1}{c}{ Karakteristik } & $\begin{array}{c}\text { Hasil } \\
\text { Analisis }\end{array}$ & SNI 2013 \\
\hline Hedonik & 3,52 & Normal $^{\mathrm{a}}$ \\
penampakan & & \\
Hedonik aroma & 3,34 & Normal $^{\mathrm{a}}$ \\
Hedonik rasa & 3,54 & Normal $^{\mathrm{a}}$ \\
Hedonik tekstur & 3,52 & Normal $^{\mathrm{a}}$ \\
Fisika kekenyalan & 9,32 & - \\
Kadar protein & 9,41 & Minimum 5,0 $^{\mathrm{a}}$ \\
Kadar lemak & 1,09 & Maksimum 16,0 $^{\mathrm{a}}$ \\
Kadar air & 51,33 & Maksimum 60,0 $^{\mathrm{a}}$ \\
Kadar abu & 1,97 & Maksimum 2,0 \\
Kadar karbohidrat & 36,20 & - \\
Kadar serat & 6,65 & - \\
pangan & & \\
\hline astandar nasional indonesia 7757:2013 &
\end{tabular}

\section{KESIMPULAN}

Penambahan tepung ampas tahu berpengaruh nyata terhadap kadar serat pangan dan organoleptik otak-otak ikan. Penambahan tepung ampas tahu tebaik yaitu pada perlakuan $5 \%$ penambahan tepung ampas tahu dengan kadar serat pangan sebesar $6,65 \%$, serat pangan larut $2,69 \%$, serat pangan tidak larut sebesar 3,96\%, protein sebesar $9,41 \%$, kadar air sebesar $51,33 \%$, lemak $1,09 \%$, abu $1,97 \%$ dan karbohidrat sebesar $36,20 \%$, hedonik kenampakan sebesar 3,52, hedonik aroma sebesar 3,34, hedonik rasa sebesar 3,54 dan hedonik tekstur sebesar 3,52 dan kekenyalan sebesar 9,32. Sehingga penambahan tepung ampas tahu pada produk otak-otak dapat meningkatkan kadar serat.

\section{DAFTAR PUSTAKA}

[1] Anggraini, S., Ansharullah, dan A. B. Patadjai. 2017. Studi penambahan tepung sagu termodifikasi terhadap kualitas sensorik dan fisikokimia otak-otak cumi. Jurnal Sains dan Teknologi Pangan. 2 (3): 590-603. 
[2] Aryani, Dwi. 2017. Asupan serat pangan dan pengetahuan tentang serat pada remaja di dua sekolah menengah atas kota bogor. Departemen Gizi Masyarakat. Fakultas Ekologi Manusia. Institut Pertanian Bogor.

[3] Sulistiyani. 2004. Pemanfaatan ampas tahu dalam pembuatan tepung tinggi serat dan protein sebagai alternatif bahan baku pangan fungsional. Skripsi. Fakultas Pertanian, Institut Pertanian Bogor.

[4] Yustina, I, dan Farid R. Abadi. 2012. Potensi tepung dari ampas industry pengolahan kedelai sebagai bahan pangan. Seminar Nasional: Kedaulatan Pangan dan Energi. Fakultas Pertanian Universitas Trunojoyo Madura.

[5] Martiana, P. Ayu. 2015 Eksperimen pembuatan sosis ikan lele dumbo (Clarias gariepinus) dengan penambahan wortel. Skripsi. Fakultas Teknik Universitas Negeri Semarang.

[6] Adhimah, N. N., A. H. Mulyati, dan D. Widiastuti. 2017. Substitusi tepung terigu dengan tepung ampas kedelai pada produk cookies yang kaya akan serat pangan dan protein. Ekologia. vol. 17, no. 1, hal. 28-39.

[7] Fransiska dan Welly Deglas. 2017. Pengaruh penggunaan tepung ampas tahu terhadap karakteristik kimia dan organoleptic kue stick. Jurnal Teknologi Pangan. Vol. 8, no. 3, hal. 71 -179.

[8] Yustina, I, dan Farid R. Abadi. 2012. Potensi tepung dari ampas industry pengolahan kedelai sebagai bahan pangan. Seminar Nasional: Kedaulatan Pangan dan Energi. Fakultas Pertanian Universitas Trunojoyo Madura.

[9] Standar Nasional Indonesia. 2013. OtakOtak Ikan. SNI 7757:2013. Badan Standarisasi Nasional. 